
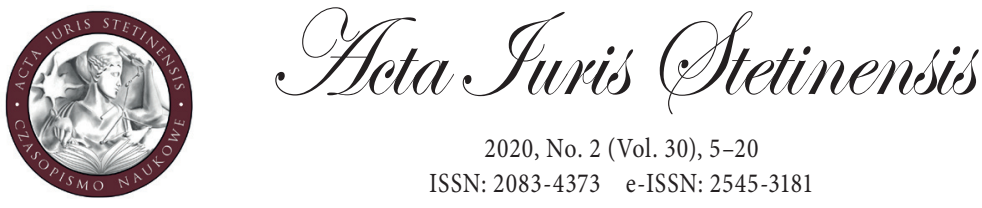

2020, No. 2 (Vol. 30), 5-20

ISSN: 2083-4373 e-ISSN: 2545-3181

DOI: $10.18276 /$ ais.2020.30-01

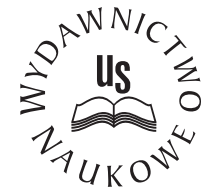

Michał Beer

MA

The John Paul II Catholic University of Lublin, Poland

e-mail:michal.beer@gmail.com

ORCID ID: 0000-0001-7187-423X

\title{
Limitation of constitutional guarantees of cultural rights in a time of pandemic
}

\begin{abstract}
The presented paper of a contributory character is aimed at examining the extent to which the constitutional guarantees of cultural rights were limited in a time of pandemic. Furthermore, the paper aims to answer the question of whether the introduced limitations in cultural rights were compliant with the principle of proportionality, if they were adequate to the actual state of affairs and whether the implemented legal measures ensured the effectiveness of law implementation. The legal sources analysed herein provide an answer to the question of whether the state has ensured alternative forms of enjoyment of products of culture and if it was obliged to do so. The paper focuses on a detailed analysis of the scope of the constitutional guarantees of cultural rights and the legal acts regulating the current state of the COVID-19 pandemic. Methods typical for legal sciences have been used herein, primarily the methodology of examining applicable laws. The legal norms analysed in the paper are included in the Constitution of the Republic of Poland, specific statutes and implementing regulations.
\end{abstract}

Keywords: cultural rights, right to participate in cultural life, limitation of human rights, pandemic, COVID-19 


\section{Introduction}

In the 21st century, in European democratic states, the general belief in the existence of strong protection of human rights, including so-called cultural rights, seems to be so high that the situations of limiting these rights could be considered as non-existent in the awareness of the general public. Constitutional provisions allowing for limitation of these rights in special situations often seem hypothetical, and the norms stipulating states of emergency can only remind one of the martial law introduced in the years 1981-83 and the era of the Polish People's Republic and thus seem to be more archaic. Meanwhile, on 11 March 2020, due to the new type of coronavirus, SARS-CoV-2, and cases of COVID-19 disease quickly spreading throughout the world, the World Health Organization (WHO) announced a state of pandemic.1 On 20 March 2020, pursuant to the Regulation of the Minister of Health, a state of epidemic was announced in the territory of the Republic of Poland, which gave the possibility to introduce restrictions provided by the law. 2

This paper, which is of a contributory character, is aimed at examining the extent to which the constitutional guarantees of cultural rights were limited in a time of pandemic. Furthermore, the paper aims to answer the question of whether the introduced limitations in cultural life were compliant with the principle of proportionality, if they were adequate to the actual state of affairs and whether the implemented legal measures ensured the effectiveness of law implementation. Finally, the legal sources analysed herein provide the answer to the question if the state has ensured alternative forms of enjoyment of products of culture and if it was obliged to do so.

Methods typical for legal sciences have been used herein, primarily the methodology of examining existing laws. The legal analysis covered the legal norms included in the provisions of the Constitution of the Republic of Poland, specific statutes and regulations concerning the state of epidemic, as well as local law acts concerning the functioning of cultural institutions.

1 World Health Organization, WHO Director-General's opening remarks at the media briefing on COVID-19, 11.03.2020, https://www.who.int/dg/speeches/detail/who-director-general-s-openinga-remaraks-at-the-media-briefing-on-covid-19---11-march-2020 (accessed 13.06.2020).

2 Regulation of the Minister of Health of 20 March 2020 on the announcement of the state of epidemic in the territory of the Republic of Poland - Dz.U. (Journal of Laws) 2020 item 491. 


\section{Constitutional guarantees of cultural rights}

In the doctrine of human rights, apart from economic and social rights, cultural rights are, in principle, included in the concept of second generation rights; they primarily include the right to access products of culture and participate in cultural life. ${ }^{3}$ Contrary to first generation rights (civil and political rights), which have a character of rights with immediate effect, second generation rights are of a progressive nature, i.e. execution of these rights depends on the level of the state's development, including economic condition. ${ }^{4}$

Cultural rights belong to the group of the so-called derogable rights. It is possible to revoke their validity in exceptional situations. ${ }^{5}$ In the doctrine of human rights, the ban on slavery, the ban on torture, the ban on inhumane treatment and

3 Drzewicki, K., Prawa człowieka, in: Przyborowska-Klimczak, A. and Pyć, D. (eds.), Leksykon prawa międzynarodowego publicznego. 100 podstawowych pojęć, Warszawa 2012, p. 350. Cultural rights are not limited only to second generation rights. Rights included in this group can be found among the rights of all generations - the right to freedom of artistic expression and creation (first generation), the right to access products of culture and participate in cultural life (second generation), the right to mutual heritage of humanity (third generation), the right of minorities to preserve their culture (fourth generation). See: Kosińska, A., Horyzontalne stosowanie praw kulturalnych, in: Młynarska-Sobaczewska, A. and Radziewicz, P. (eds.), Horyzontalne oddziaływanie konstytucji Rzeczypospolitej Polskiej oraz Konwencji o ochronie praw człowieka i podstawowych wolności, Warszawa 2015, p. 176. In the established scholarship, apart from classical cultural rights of the second generation, other cultural rights are also discussed. The source of distinguishing these rights consists in the so-called Fribourg Declaration on Cultural Rights of 2007. It is not a legally binding act; however, it enumerates rights such as: the right to respect individual's cultural identity, the right to learn about and respect own culture, the right to access cultural heritage, the freedom of cultural expression in a public or private space and the right to education and information, as rights related to participation in cultural life and the right to cultural cooperation see: Kosińska, A., Prawa kulturalne obywateli państw trzecich w prawie Unii Europejskiej, Lublin 2018, p. 24.

4 The issues related to the uniform classification of cultural rights are also commented on sceptically by A. Młynarska-Sobaczewska, who notices that "(...) such a classification of the right to participate in culture is slightly misleading”; Młynarska-Sobaczewska, A., Prawo do kultury, Warszawa 2018, p. 63.

5 In compliance with Article 233 of the Constitution of the Republic of Poland, "1. The statute specifying the scope of limitation of the freedoms and rights of persons and citizens in times of martial law and states of emergency shall not limit the freedoms and rights specified in Article 30 (the dignity of the person), Article 34 and Article 36 (citizenship), Article 38 (protection of life), Article 39, Article 40 and Article 41 para. 4 (humane treatment), Article 42 (ascription of criminal responsibility), Article 45 (access to a court), Article 47 (personal rights), Article 53 (conscience and religion), Article 63 (petitions), as well as Article 48 and Article 72 (family and children). 2. Limitation of the freedoms and rights of persons and citizens only by reason of race, gender, language, faith or lack of it, social origin, ancestry or property shall be prohibited." 
the right to life are considered to be non-derogable rights. ${ }^{6}$ Apart from revocation, it is also possible to limit human rights via so-called limitation clauses. In principle, human rights do not have a character of absolute rights, thus, it is possible to limit them in a justified situation, e.g. in order to protect the rights of other persons. ${ }^{7}$

In the Constitution of the Republic of Poland, cultural rights were regulated in an incomplete manner; this results from the fact that the right to access products of culture and participate in cultural life was included in Chapter I "The Republic of Poland" in Articles 5 and 6, which include so-called general rules, and thus, subjective rights cannot be deduced therefrom. ${ }^{8}$ The only regulated and constitutionally guaranteed (in Chapter II of the Constitution) right of a cultural character or, in fact, cultural freedom in se is the freedom of artistic creation and the freedom to enjoy products of culture guaranteed in Article 73 of the Constitution of the Republic of Poland. ${ }^{9}$ This provision is the only one that includes guarantees of the so-called broadly understood cultural rights in Chapter II of the Constitution of the Republic of Poland. ${ }^{10}$ Whereas it should be noted that Chapter II does not stipu-

6 Gronowska, B. et al., Prawa człowieka i ich ochrona, Toruń 2010, p. 221.

7 Wiśniewski, A., Klauzula limitacyjna, in: Balcerzak, M. and Sykuna, S. (eds.), Leksykon ochrony praw człowieka. 100 podstawowych pojęć, Warszawa 2010, p. 189.

8 Thus, in compliance with Article 5, "The Republic of Poland shall safeguard the independence and integrity of its territory and ensure the freedoms and rights of persons and citizens, the security of the citizens, safeguard the national heritage and shall ensure the protection of the natural environment pursuant to the principles of sustainable development." Whereas in compliance with Article 6 par. 1, "1. The Republic of Poland shall provide conditions for the people's equal access to products of culture which are the source of the Nation's identity, continuity and development." The Constitution of the Republic of Poland of 2 April 1997, adopted by the National Assembly on 2 April 1997, approved by the Nation in the Constitutional Referendum on 25 May 1997, signed by the President of the Republic of Poland on 16 July 1997 (Dz.U. (Journal of Laws) of 1997 No. 78 item 483 as amended). As underlined by P. Tuleja, "Article 5 of the Constitution stipulates the basic aims of the Republic of Poland. They were expressed in the form of programme principles. They indicate the directions of the state's activities; however, they do not stipulate the means and manners of execution thereof. In Article 5, the legislator imposes on all public authorities the obligation to execute indicated aims." Tuleja, P., Komentarz do art. 5 Konstytucji, in: Tuleja, P. (ed.), Konstytucja Rzeczypospolitej Polskiej. Komentarz, Warszawa 2019, www.lex.sip.pl (accessed 10.05.2020).

9 In compliance with Article 73 of the Constitution of the Republic of Poland, "The freedom of artistic creation and scientific research as well as dissemination of the fruits thereof, the freedom to teach and to enjoy products of culture, shall be ensured to everyone." For more on the subject matter of the concept of "products of culture" not identified in the Constitution of the Republic of Poland, see: Frankiewicz, A., Znaczenie prawne regulacji dziedzictwa narodowego i dóbr kultury w Rozdziale I Konstytucji RP, "Przegląd Prawa i Administracji” 2012, No. 88, pp. 9-22.

10 Kosińska, A., Szczególny charakter praw kulturalnych i ich miejsce w Konstytucji RP - próba charakterystyki i kwalifikacji, "Przegląd Prawa Konstytucyjnego" 2013, No. 3, p. 22. 
late any cultural right of a restitutionary nature (second generation right), apart from Article 35 guaranteeing the rights of national minorities. Thus, guarantees of cultural rights in the Polish Constitution should be considered as incomplete and insufficient.

As underlined by Paweł Sarnecki, "Article 6 is formulated in a much more definite manner than Article 5; therefore, it should be classified as one of the more specific principles of the state policy"11 - principles of implementation of state policies in the area of ensuring access to products of culture are regulated by legal norms included in specific statutes, such as e.g. the Act on museums, the Act on libraries or the Act on cinematography.

For comparison, the sphere of cultural rights was regulated in a different manner guaranteeing execution thereof to a fuller extent in the Constitution of the Czech Republic. Reference to culture and national heritage was included in the Preamble, ${ }^{12}$ whereas Article 3 introduces the Charter of Fundamental Rights and Freedoms as an integral part of the constitutional order of the Czech Republic. ${ }^{13}$ Such a solution unburdens the fundamental law, and with regard to the access to products of culture, it references in Article 34 par. 2 specific statutes. A similar solution, providing for attaching the Charter of Fundamental Rights and Freedoms to the Constitution of the Republic of Poland, as well as detailed regulations on access to products of culture, was included in the draft of the Constitution submitted by President Lech Wałęsa. ${ }^{14}$

Standards of cultural rights' guarantees are also stipulated on the grounds of international agreements binding the Republic of Poland. In the universal system for the protection of human rights, these are the International Covenant on Civil and Political Rights ${ }^{15}$ and the International Covenant on Economic, Social and Cultural Rights. ${ }^{16}$ States Parties to the International Covenant on Economic, Social

11 Sarnecki, P., Komentarz do art. 6 Konstytucji RP, in: Garlicki, L. and Zubik, M. (eds.), Konstytucja Rzeczypospolitej Polskiej. Komentarz. Tom I, wyd. II, Wydawnictwo Sejmowe 2016, www.sip.lex.pl (accessed 11.05.2020).

12 Constitution of the Czech Republic of 16 December 1992, constitutional act no. 1/1993 Coll., Sb. English version of the Constitution available at - http://www.servat.unibe.ch/icl/ez00000_html (accessed 11.05.2020).

13 Charter of Fundamental Rights of the European Union, OJ C 202, 7.06.2016, pp. 391-407, p. 389.

14 Kosińska, A., Szczególny charakter praw..., p. 23.

15 International Covenant on Civil and Political Rights, 16 December 1966, United Nations, Treaty Series, Vol. 999, pp. 171-346.

16 International Covenant on Economic, Social and Cultural Rights, 16 December 1966, United Nations, Treaty Series, Vol. 993, pp. 3-106. 
and Cultural Rights were given the freedom of creating own policy in order to implement the provisions of the Covenant, and in compliance with the progressive character of second generation rights, "(...) achieving progressively the full realisation of the rights (...)"17 was permitted. Particular focus was placed on the ban on discrimination due to sex. Apart from Article 2 par. 2, in which the obligation not to discriminate on the basis of sex was enumerated among factors such as race, colour, language, religion, political opinion, national or social origin, property status or birth, Article 3 was devoted to the issue of guaranteeing equal access of women and men to exercising economic, social and cultural rights. Article 15 includes guarantees of such cultural rights as the right of everyone: "to take part in cultural life; to enjoy the benefits of scientific progress and its applications; to benefit from the protection of the moral and material interests resulting from any scientific, literary or artistic production of which he is the author". In order to reinforce the mechanism of controlling adherence to the rights enumerated in the Covenant, the Optional Protocol was adopted, ${ }^{18}$ in which States Parties recognise the competence of the Committee on Economic, Social and Cultural Rights to consider cases concerning infringement of second generation rights. Poland ratified both Covenants; however, it has not yet decided to join the Optional Protocol to the International Covenant on Economic, Social and Cultural Rights. ${ }^{19}$ However, three mechanisms of control included in the protocol: an individual complaint, so-called complaint between States Parties to the Protocol, as well as initiation of proceedings by the Committee on its own initiative (whereas, in the case of two last mechanisms, on the condition of a consent of the State Party whom the proceedings concern), do not include sanctions per se. Proceedings before the Committee are completed with a report including conclusions and recommendations for the State Party to the Covenant.

The European (regional) system for the protection of human rights with acts binding the Republic of Poland includes the Convention for the Protection of Human Rights and Fundamental Freedoms (hereinafter referred to as: ECHR). ${ }^{20}$ The ban on discrimination is guaranteed by Article 14 of the ECHR, in compliance with which "the enjoyment of the rights and freedoms set forth in this Convention

17 Ibidem, Article 2(1).

18 Optional Protocol to the International Covenant on Economic, Social and Cultural Rights: resolution adopted by the General Assembly, 5 March 2009, A/RES/63/117.

19 Current States Parties to the Protocol, United Nations Treaty Collection, https://treaties.un.org/Pages/ ViewDetails.aspx?src=TREATY\&mtdsg_no=IV-3-a\&chapter=4\&lang=en $($ accessed 19.05.2020).

20 European Convention for the Protection of Human Rights and Fundamental Freedoms, as amended by Protocols Nos. 11 and 14, 4 November 1950, ETS 5. 
shall be secured without discrimination on any ground such as sex, race, colour, language, religion, political or other opinion, national or social origin, association with a national minority, property, birth or other status." The ECHR itself does not provide for the protection of second generation rights, and thus, the protection of cultural rights has not been guaranteed (the Convention does not even guarantee the freedom of artistic creativity despite the fact that this freedom is included in the first generation of human rights). Cultural rights sensu largo are included in optional protocols (e.g. in Protocol 1 - Article 2 guarantees the right to education). Despite the above, the European Court of Human Rights, which guarantees adherence to the ECHR, by reinterpretation of Convention's Articles, distinguished cultural rights sensu largo. The reinterpretation primarily covered Article 8 (the right to respect for private and family life), Article 9 (the right to freedom of thought, conscience and religion) and Article 10 (the right to freedom of expression), ${ }^{21}$ from which the right to freedom of artistic creativity, as well as the right to participate in cultural life, as e.g. in the case of Mustafa and Tarzibachi, ${ }^{22}$ were distinguished.

Moreover, guarantees of the protection of fundamental rights in the EU legal system do not provide for full protection of cultural rights. The Charter of Fundamental Rights ${ }^{23}$ was adopted by Poland and the United Kingdom with reservations expressed in the so-called British Protocol, ${ }^{24}$ in compliance with which guarantees of rights expressed in the Charter cannot exceed those binding in national law. Article 22 of the Charter of Fundamental Rights, included in Chapter III "Equality", stipulates that "The Union shall respect cultural, religious and linguistic diversity." The genesis of establishing the European Union consisted in the need of regulating economic relations; therefore, competences of the Union have a supportive character (pursuant to Article 6 of the TFEU), ${ }^{25}$ and thus, cultural rights are protected primarily at the national level.

21 ECtHR, Cultural rights in the case-law of the European Court of Human Rights, Council of Europe/ European Court of Human Rights, January 2011, p. 4.

22 Case 23883/06 Khurshid Mustafa and Tarzibachi v. Sweden, ECLI:CE:ECHR:2008:1216JUD002388306 .

23 Charter of Fundamental Rights of the European Union, OJ C 202, 7.06.2016, pp. 389-405.

24 Protocol (No. 30) on the Application of the Charter of Fundamental Rights of the European Union to Poland and to the United Kingdom to the Treaty on the Functioning of the European Union, OJ C 326, 12.10.2012, pp. 313-314.

25 Treaty on the Functioning of the European Union, consolidated version, OJ C 202, 7.06.2016, pp. 47-390. 


\section{Legal regulations concerning the state of epidemic and the state of epidemic threat in the context of realisation of guarantees of cultural rights and implementation thereof}

Article 31 par. 3 of the Constitution of the Republic of Poland, included in Chapter II "The freedoms, rights and obligations of persons and citizens", formulates a general limitation clause of the following wording: "Any limitation upon the exercise of constitutional freedoms and rights may be imposed only by statute, and only when necessary in a democratic state for the protection of its security or public order, or to protect the natural environment, health or public morals, or the freedoms and rights of other persons. Such limitations shall not violate the essence of freedoms and rights." This clause opens, upon fulfilment of conditions included therein, the possibility to stipulate, under a statute, limitations on benefiting from constitutionally guaranteed freedoms and rights, as well as those included in Article 73 and concerning the freedom of artistic creativity and the freedom to benefit from products of culture. Furthermore, an important condition consists in these limitations not infringing upon the essence of freedoms and rights. Therefore, a question arises regarding the essence of the freedom of artistic creativity and the freedom to benefit from products of culture. The catalogue of rights constituting particular guarantees of fundamental rights is wide. This causes difficulties in specifying the essence of these freedoms. One may attempt to describe this essence negatively. An infringement of the essence of the freedom of artistic creativity would consist in a ban on all forms of realisation thereof, whereas, in the case of the freedom of benefiting from products of culture, preventing access thereto in any form. Undoubtedly, the essence of these freedoms will not be infringed upon solely by a ban on organising artistic events or closing a museum for visitors. These are only some of many manifestations of realising the guarantee of a specific cultural right.

In the discussed period of the SARS-CoV-2 pandemic, the basic legal act allowing limitation of cultural rights was the Act of 5 December 2008 on preventing and combating infections and infectious diseases among people. ${ }^{26}$ In compliance with Article 46 par. 2 of the Act, "If an epidemic threat or epidemic is present in the area of more than one voivodeship, the state of epidemic threat or the state of epidemic

26 Act of 5 December 2008 on preventing and combating infections and infectious diseases among people, Dz.U. (Journal of Laws) 2008 No. 234, item 1570 as amended. Pursuant to Article 3 par. 2 of this Act, under the Regulation of the Minister of Health of 27 February 2020 on infection by SARS-CoV-2, Dz.U. (Journal of Laws) 2020 item 325, infection by SARS-CoV-2 was covered with provisions thereof. 
is announced and recalled, under a regulation, by the Minister of Health in agreement with the Minister of Interior and Administration, upon the request of the Chief Sanitary Inspector." Whereas par. 4 of Article 46 specifies what limitations, bans, orders and obligations can be stipulated in the regulation. These are the following: “(...) 1) temporary limitation of a specific way of movement, 2) temporary limitation of or a ban on the turnover and use of specific objects or foodstuff, 3) temporary limitation of operations of specific institutions or places of employment, 4) a ban on organising shows and other gatherings, 5) an obligation to perform specific sanitary treatments, if performance thereof is related to the operations of specific production, service provision, commercial or other facilities, 6) an order to provide access to property, premises, terrains and to provide means of transport for anti-epidemiological activities specified in anti-epidemiological plans, 7) an obligation to perform preventive vaccinations (...)".27

Another act providing wide competences to voivodes (and, upon the request of the voivode, to the Prime Minister) was the Act of 2 March 2020 on specific solutions related to the prevention, counteraction and eradication of COVID-19, other infectious diseases and crisis situations caused by them. ${ }^{28}$ Pursuant to this Act, with regard to the prevention of COVID-19, it became possible for voivodes to issue orders subject to immediate execution in relation to all government administration authorities operating in the voivodeship and state legal persons, local government authorities, self-government legal persons and unincorporated local government units. Such orders, upon the voivode's request, can also be issued by the Prime Minister with regard to legal persons and unincorporated organisations, as well as entrepreneurs. The above orders can be issued "orally, by phone, by means of electronic communication or other means of communication". ${ }^{29}$

With regard to the limitation of cultural rights, the Act of 25 October 1991 on organising and running cultural activity should also be mentioned. ${ }^{30}$ This Act

27 “(...) considering the channels of spreading infections and infectious diseases, as well as the epidemic situation in the area where the state of epidemic threat or the state of epidemic has been announced" - see full text of Article 46 par. 2.

28 Act of 2 March 2020 on specific solutions related to the prevention, counteraction and eradication of COVID-19, other infectious diseases and crisis situations caused by them, Dz.U. (Journal of Laws) 2020 item 374, Article 11(1), (2), (7).

29 Act on specific solutions..., op. cit., Article 11(10).

30 Act of 25 October 1991 on organising and running cultural activity, Dz.U. (Journal of Laws) 2020 item 194. 
includes the voivode's authorisation to order suspension of organisation of artistic events in the territory of the voivodeship or a part thereof to prevent an epidemic. ${ }^{31}$

On 11 March 2020, a week after disclosing the first case of COVID-19 in Poland, during the meeting of the Government Crisis Management Team ${ }^{32}$ with the participation of the Minister of Culture and National Heritage, it was decided to temporarily close, as of 12 March 2020, cultural institutions, philharmonics, operas, operettas, theatres, museums, cinemas, community centres, libraries, art galleries and schools, universities and artistic education facilities. ${ }^{33}$ Simultaneously, by orders of voivodes in all voivodeships, as of 12 March 2020, organisation of artistic and entertainment events, in particular in: theatres, operas, operettas, philharmonics, cinemas, museums, community centres and art galleries, was suspended. Furthermore, all planned events were cancelled, about which the society was also informed via institutions' social media profiles. Thus, at this stage, both the freedom of artistic creativity and the freedom to benefit from products of culture were indirectly limited. What is interesting is that there was no consistent narration of various cultural institutions with regard to the grounds for closing them. In the case of the Lublin Museum, it was stated that it had been the decision of the Minister of Culture and National Heritage, the Historical Museum in Sanok informed it was the government's decision, whereas the National Museum in Warsaw stated the decision made by the crisis management centre with the participation of the Minister of Culture and National Heritage. ${ }^{34}$ This can be explained with, on the one hand, the parallel actions of voivodes, whose competences pursuant to the Act of 2 March 2020 on specific solutions related to the prevention, counteraction and eradication of COVID-19, other infectious diseases and crisis situations caused by them

31 Ibidem, Article 37(2) in conjunction with Article 2.

32 The Government Crisis Management Team is an opinion-forming and advisory authority, relevant in initiation and coordination of measures undertaken in the scope of crisis management (Act of 26 April 2007 on crisis management, Dz.U. (Journal of Laws) 2019, item 1398, Articles 8 and 9).

33 \#Koronawirus: Zawieszenie działalności instytucji kultury i placówek szkolnictwa artystycznego, 11.03.2020, Ministry of Culture and National Heritage, https://www.gov.pl/web/kultura/zawieszenie-dzialalnosci-instytucji-kultury-i-placowek-szkolnictwa-artystycznego (accessed 18.06.2020).

34 Example of information from the Facebook profile of the Lublin Museum https://www.facebook. com/MuzeumLubelskie/posts/2879188922138228, the Historical Museum in Sanok https://www. facebook.com/muzeumhistoryczne.wsanoku/posts/1800 142033454799, or the National Museum in Warsaw https://www.mnw.art.pl/aktualnosci/muzeum-narodowe-w-warszawie-wraz-z-oddzialami-zamkniete-od-1203,590.html (accessed 18.06.2020). 
included issuing orders (among others, verbally, by phone, via email). ${ }^{35}$ Undoubtedly, by closing cultural facilities, access to products of culture was significantly limited, since the state patronage over culture and cultural policy executed by the state plays a significant role in developing Poles' cultural participation. When considering e.g. the issue of access to books, they were available at bookstores; however, as a result of closing libraries, cultural participation depended to a certain extent on financial resources. In 2018, in Poland, there were 7,925 public libraries, of which $65.4 \%$ operated in rural areas, and there were 6 million persons actively using the resources thereof. ${ }^{36}$ Moreover, closure of cultural facilities limited collective forms of cultural participation. "In 2019, cultural centres, community centres, cultural institutions, clubs and clubrooms in total organised 243.8 thousand events, which were participated in by 37.5 million persons". ${ }^{37}$ Due to the fact that culture is a collective phenomenon, collective participation is extremely important.

On 20 March 2020, due to the growing number of COVID-19 cases, the Regulation of the Minister of Health on the announcement of the state of epidemic in the territory of the Republic of Poland entered into force on the day of its announcement. ${ }^{38}$ The possibility to restrict cultural rights and freedoms provided for by the Act on preventing and combating infections and infectious diseases among people was used in the construction of legal norms included in the Regulation. In Chapter 4 of the Regulation, entitled "Restrictions of the functioning of specific institutions or places of employment", par. 6 subpar. 1 point 1, activity conducted by entrepreneurs and other entities was subject to temporary limitation - in letter c) creative activity related to any collective forms of culture and entertainment; in letter d) activity related to sport, entertainment and recreation, in particular consisting in running meeting places, clubs, including dance clubs and nightclubs, as well as swimming pools, gyms, fitness clubs; in letter e) activity related to screenings of films or video recordings in cinemas, in the open air or in other places, as well as the activity of film clubs. In point 2 , the activity of libraries, archives, museums and other activ-

35 Act on specific solutions..., op. cit., Article 11(7).

36 GUS, Kultura w 2018 roku, 30.09.2020, Warszawa, Kraków 2019, pp. 40-41, https://stat.gov.pl/ obszary-tematyczne/kultura-turystyka-sport/kultura/kultura-w-2018-roku,2,16.html (accessed 24.06.2020).

37 GUS, Działalność centrów kultury, domów kultury, ośrodków kultury, klubów i świetlic w 2019 roku, 08.06.2020, p. 1, https://stat.gov.pl/obszary-tematyczne/kultura-turystyka-sport/kultura/dzialalnosc-centrow-kultury-domow-kultury-osrodkow-kultury-klubow-i-swietlic-w-2019-roku,9,3. html (accessed 24.06.2020).

38 Regulation of the Minister of Health of 20 March 2020, op. cit. 
ity related to culture was temporarily limited, whereas in point 4 , presiding over religious worship in public places, including buildings and other facilities of religious cult, was also temporarily limited.

Moreover, it was specified that the limitations referred to in par. 6 subpar. 1 points 1 and 2 consist in a complete ban on conducting activity. With regard to point 4 (exercising religious worship), it was also specified that this limitation consists in " (...) the necessity to ensure that in the course of exercising religious worship in a given area or at a given facility, there are no more than 50 persons in total, both inside and outside premises, including participants and persons presiding over religious worship." This means that while restrictions regarding point 4 actually have a limitative nature (activity consisting in exercising religious worship can still be conducted with certain restrictions), the absolute ban covered the activity of libraries, archives, museums and other activities related to culture, which, in compliance with the statutory delegation, can be covered not with a ban but a temporary restriction. It should be remembered that in the Act on preventing and combating infections and infectious diseases among people, the legislator uses, among others, the concepts of a limitation and a ban, and it seems that these concepts are not equivalent. Furthermore, it seems legitimate to formulate a conclusion de lege ferenda, in compliance with which, in the case of libraries, archives, museums and other institutions, it would be valid to restrict per analogiam exercising religious worship, the more so since benefiting from both forms of access to culture contributes to the development of cultural identity and thus execution of cultural rights.

Moreover, it should also be noticed that on the occasion of drawing up the Regulation, the guidelines given in the Regulation of the Prime Minister of 20 June 2002 on "Principles of legislative technique", which introduces the concept of episodic provisions which "(...) stipulate regulations, which introduce deviations from specific provisions and the binding period of which is explicitly specified", were not adhered to. In compliance with par. 29b, “(...) the binding period of the regulation is specified in episodic provisions in particular by: 1) specifying the calendar year or calendar years; 2) determining the start and end point of the regulation's validity, expressed with calendar days; 3 ) indicating the number of days, weeks, months or years that pass from the day of entering into force of the Act or specific provisions thereof." Despite the fact that this catalogue is not closed (by using the expression "in particular"), it seems that it indicates the need to provide the end date or the binding period of the episodic provision. The Act includes a delegation to stipulate in the Regulation specific restrictions or bans of a temporary nature. One should consider the character of the Regulation's provisions, for which no end date of 
validity thereof was given. The Regulation only includes the binding period of the state of epidemic, whereas this period is closed with an expression "until further notice".

Chapter 5 of the discussed Regulation introduced, in compliance with the title, a ban on organising shows and other gatherings, whereas an exception to applying this ban was introduced " $(\ldots)$ in case the number of gathering's participants does not exceed 50 persons, including the organiser and persons acting on his behalf."

In the next stages of epidemic, the Regulation of 20 March was amended with the Regulation of 24 March by introducing, among others, a temporary ban on movement. ${ }^{39}$ Moreover, exceptions from the ban regarding movement, among others, in order to meet necessary everyday needs and exercising or participating in religious worship, including religious activities or rituals, were stipulated. Incidentally, one can note that the introduced temporary ban on movement also influenced the freedom of benefiting from products of culture (guaranteed nota bene in Article 73 of the Constitution), especially with regard to access to broadly understood products of culture (such as churches and other historic backdrop in the development of e.g. cities/towns) in public space.

\section{Conclusions}

On the grounds of the source materials analysed herein, the following answers can be provided to the research theses. The first research question concerned the issue of the extent to which constitutionally guaranteed cultural rights were limited during the pandemic. It should be noted that during the pandemic, both the freedom of artistic creativity and the freedom to benefit from products of culture were limited, but only indirectly, since statutorily, on the grounds of Article 31 par. 3 of the Constitution, they were not limited. The introduced limitations did not concern constitutional freedoms and rights but particular powers being the components thereof. However, activities such as closing cultural institutions had an indirect impact on the possibilities of benefiting from products of culture.

One should then answer the question of whether the introduced limitations in cultural life were compliant with the principle of proportionality, if they were adequate to the actual state of affairs and whether the implemented legal measures

39 On the lack of legal grounds for establishing a ban on movement without the introduction of a state of emergency, see: Wilk, J., Prawo do przemieszczania się $w$ stanie epidemii - brak podstaw prawnych dla wprowadzania zakazu przemieszczania się, www.lex.sip.pl (accessed 24.06.2020). 
ensured the effectiveness of law implementation. Taking into account the answer to the first question regarding the level of limitation of constitutionally guaranteed cultural rights and the fact of the lack of introduction of statutory limitations on the grounds of Article 31 par. 3 of the Constitution, in principle, it is not necessary to answer this question. Incidentally, it can be noted that the legal measures applied in order to limit cultural activity for the period of a pandemic raise certain doubts with the author with regard to the introduced total ban on visiting museums in comparison with the possibility of exercising religious worship, which was not completely banned. This issue raises certain doubts as to the proportionality of measures proposed by the legislator.

Finally, the legal sources analysed herein provide the answer to the question of whether the state has ensured alternative forms of the enjoyment of products of culture and if it was obliged to do so. None of the pandemic legal acts directly obliged cultural institutions to undertake remote activities (it is worth mentioning that the system of education and higher education was directly obliged to undertake such activities under legal norms). Despite the lack of such obligations, undertaking actual and effective activities by cultural institutions in the area of promotion and access to products of culture, primarily online, can be considered good practice.

Despite limitations in moving and organising events of an artistic and cultural nature, as well as the closing of museums, galleries and other cultural facilities, employees of these institutions, as well as the society, created and actively joined the \#stayathome action. ${ }^{40}$ In 2019, $86.7 \%$ of households had access to online resources and thus the potential possibility to have online contact with products of culture, among others, from museum collections. ${ }^{41}$ Nevertheless, it should be remembered that together with the blessings of the Internet, that is, undoubtedly, the universality, speed and ease of access to collections the user is interested in, we also experience negative aspects of using the web - the so-called access to products of mediated culture due to the fact that "(...) poor quality of reproductions does not provide the idea of original copies. On occasion, it should be reminded that a painting - oil on canvas, fresco, watercolour - is a genuine thing, an exceptional

40 Events of a broadly understood cultural character, as well as museum collections transmitted and shared online, in particular, on the social platform Facebook, were marked with the hashtag \#stayathome in order to make them easier to find and promote access to culture in a time of pandemic. See e.g. marked with \#stayathome and shared online collections of KUL Museum, https://www. facebook.com/PZM.KUL/posts/2864719753611359 (accessed 22.06.2020).

41 GUS, Społeczeństwo informacyjne w Polsce w 2019 roku, 21.10.2019, https://stat.gov.pl/obszarytematyczne/nauka-i-technika-spoleczenstwo-informacyjne/spoleczenstwo-informacyjne/spoleczenstwo-informacyjne-w-polsce-w-2019-roku,2,9.html (accessed 22.06.2020). 
object, the surface and depth of which can be assessed only while in contact therewith, when the viewer's location with regard to the work is the same as the creator's (...). Photographs of paintings are only their pale shadows; just as scores including notes, which are only a record of something else. Contemporary painting is much too often experienced second hand. Digital files back-highlighted on screens and reproductions in books and magazines are poor substitutes of a dialogue with an original work" ${ }^{42}$

\section{References}

ECtHR, Cultural rights in the case-law of the European Court of Human Rights, Council of Europe/European Court of Human Rights, January 2011.

Drzewicki, K., Prawa człowieka, in: Przyborowska - Klimczak, A. and Pyć, D. (eds.), Leksykon prawa międzynarodowego publicznego. 100 podstawowych pojęć, Warszawa 2012.

Frankiewicz, A., Znaczenie prawne regulacji dziedzictwa narodowego i dóbr kultury w Rozdziale I Konstytucji RP, "Przegląd Prawa i Administracji” 2012, No. 88.

Gronowska, B. et al., Prawa człowieka i ich ochrona, Toruń 2010.

GUS, Działalność centrów kultury, domów kultury, ośrodków kultury, klubów i świetlic w 2019 roku, 08.06.2020, https://stat.gov.pl/obszary-tematyczne/kultura-turystyka-sport/kultura/dzialalnosc-centrow-kultury-domow-kultury-osrodkow-kulturyklubow-i-swietlic-w-2019-roku,9,3.html.

GUS, Kultura w 2018 roku, Warszawa, Kraków 2019, 30.09.2020, https://stat.gov.pl/obszary-tematyczne/kultura-turystyka-sport/kultura/kultura-w-2018-roku,2,16.html.

GUS, Społeczeństwo informacyjne w Polsce w 2019 roku, 21.10.2019, https://stat.gov.pl/ obszary-tematyczne/nauka-i-technika-spoleczenstwo-informacyjne/spoleczenstwo-informacyjne/spoleczenstwo-informacyjne-w-polsce-w-2019-roku,2,9.html.

Karpeles, E., Prawie nic. Józef Czapski. Biografia malarza, Warszawa 2019.

Kosińska, A., Horyzontalne stosowanie praw kulturalnych, in: Młynarska-Sobaczewska, A. and Radziewicz, P. (eds.), Horyzontalne oddziaływanie konstytucji Rzeczypospolitej Polskiej oraz Konwencji o ochronie praw człowieka i podstawowych wolności, Warszawa 2015.

Kosińska, A., Prawa kulturalne obywateli państw trzecich w prawie Unii Europejskiej, Lublin 2018.

Kosińska, A., Szczególny charakter praw kulturalnych i ich miejsce w Konstytucji RP próba charakterystyki i kwalifikacji, "Przegląd Prawa Konstytucyjnego" 2013, No. 3.

42 Karpeles, E., Prawie nic. Józef Czapski. Biografia malarza, Warszawa 2019, p. 18. 
Młynarska-Sobaczewska, A., Prawo do kultury, Warszawa 2018.

Sarnecki, P., Komentarz do art. 6 Konstytucji RP, in: Garlicki, L. and Zubik, M. (eds.), Konstytucja Rzeczypospolitej Polskiej. Komentarz. Tom I, wyd. II, Warszawa 2016, www.sip.lex.pl.

Tuleja, P., Komentarz do art. 5 Konstytucji, in: Tuleja, P. (ed.), Konstytucja Rzeczypospolitej Polskiej. Komentarz, Warszawa 2019, www.lex.sip.pl.

Wilk, J., Prawo do przemieszczania się w stanie epidemii - brak podstaw prawnych dla wprowadzania zakazu przemieszczania się, www.lex.sip.pl.

Wiśniewski, A., Klauzula limitacyjna, in: Balcerzak, M., and Sykuna, S. (eds.), Leksykon ochrony praw człowieka. 100 podstawowych pojęć, Warszawa 2010.

\section{CITATION}

Beer, M., Limitation of constitutional guarantees of cultural rights in a time of pandemic, "Acta Iuris Stetinensis" 2020, No. 2 (Vol. 30), 5-20, DOI: 10.18276/ais.2020.30-01. 